\title{
LANGUAGE AND DISCOURSE AWARENESS IN MANAGEMENT EDUCATION 1
}

Critical language and discourse awareness in management education

Dr Erika Darics

Aston University, Birmingham, UK

Author note

Address: Aston Triangle, Birmingham, B4 7ET

Telephone: +44 1212044155

E-mail: e.darics@aston.ac.uk

\section{Acknowledgement}

I am very grateful for the anonymous reviewers and the associate editor for their encouragement, constructive comments and ongoing support of the ideas put forward in the essay. 


\title{
LANGUAGE AND DISCOURSE AWARENESS IN MANAGEMENT EDUCATION 2
}

\author{
Abstract \\ Communication - and, through it, language - have become key elements of business and organiza- \\ tional life. How organizations interact within their walls and with the outside world fundamentally af- \\ fects business processes, creating organizational culture, shaping public perceptions and influencing \\ consumer choices. This essay calls for a greater acknowledgement of language and communication and \\ suggests that management educators may want to review how they are incorporated in management ed- \\ ucation curricula. Expanding on the skill-based approach typically adopted in business school classes, \\ the essay points to the utility of exposing business students to the dual function of language as a means \\ of doing work and as social action that constitutes social reality. Drawing on examples from scholar- \\ ship in linguistics and discourse analysis, the essay demonstrates that the ability to notice, identify and \\ reflect on linguistic and discourse practices is a crucial managerial skill. Nurturing such analytical and \\ thinking skills not only enables people to become better communicators, but also critical thinkers able \\ to understand and challenge when social control, power or injustice is enacted in organizations. \\ Keywords: soft skills, communication skills, social constructivism, critical language awareness, dis- \\ course awareness, critical thinking, organizational discourse
}




\section{LANGUAGE AND DISCOURSE AWARENESS IN MANAGEMENT EDUCATION 3}

Communication - and, by extension, language - play fundamental roles in our everyday lives; so fundamental that many of us tend to take them for granted, rarely pausing to consider what they involve or just how important they are to us, as aptly pointed out by business consultant Thompson (2003, p. 9). In the last 20 years there has been an increasing recognition of the importance of these roles in professional and workplace settings: professionals and consultants have started to recognize the "power of words" (Czerniawska, 1997; Thompson, 2003) and high-profile business personae speak of the crucial role of language and communication (e.g. Branson, 2014).

The importance and prevalence of communication has never been so tangible in human history as it is now. On the one hand, ever improving and increasingly prevalent digital communication technologies, the worldwide web and social media platforms foster an always-on, always-connected communication practice, in both our private and professional lives. Such constant connectedness has contributed to the blurring of the boundaries between the private, public, personal and corporate spheres: employees and external stakeholders can engage in instantaneous, two-way communication with organizations (Beers-Fägersten, 2015; Creelman, 2015), many communication channels are beyond the control of an organization yet have a profound influence on its functioning (such as semi-professional blogs, employee Twitter accounts or community-initiated fan pages), and leading corporate personae are expected to share insights into their personal lives to increase trust towards the brands they represent (Girginova, 2015). This shifting relationship between organizations and their internal and external stakeholders has inevitably brought about a shift in communication practices in business. As Czerniawska, the managing director of a consultancy firm, pointed out over 20 years ago, communication - and consequently language - have become "fundamental to the way in which organizations operate internally and compete externally (and) we are much more dependent on language in business than we used to be" (1997, p. 11). Competence in understanding these new practices and their possible impact in all areas of business life has now become critical for the success of business organizations. 


\section{LANGUAGE AND DISCOURSE AWARENESS IN MANAGEMENT EDUCATION 4}

On the other hand, changed communication practices have re-defined not only how we complete but also how we make sense of work - in particular in knowledge-focused white-collar workplaces. A considerable proportion of the work people undertake in the knowledge economy is conducted in and through communicative acts: meetings, planning work and collaborating in teams, conducting interviews, solving problems and managing others in the office or in the virtual realm, or, from a corporate perspective, informing customers via a range of face-to-face or mediated communication channels, designing PR campaigns, researching and drafting financial reports and managing social media. As a result, people are often deprived of seeing actual, tangible outcomes of their efforts: achievement and efficiency are discursively constructed and measured (Crawford, 2009). Consequently, in order to be able to make sense of and perceive work as meaningful, how we talk about it becomes increasingly important. For example, Brannan, Parsons and Priola (2015) examined how employees of a call center make sense of and evaluate their jobs. Their findings show that the carefully selected wording of glossy brochures, the communication aimed at trainees during induction and continuously repeated corporate messages can lead to a perception that the workplace is more appealing and that the work is more meaningful than might be the case in reality.

\section{Communication as key competence}

In this essay, my aim is to demonstrate that the awareness of language and how it is used, as well as consciousness of how it creates and is affected by broader Discourses are crucial managerial skills. Such awareness, as I will demonstrate below, can be an important means to acquisition of communication skills in a practical sense, at the same time enabling future managers to obtain analytical and critical thinking skills. Indeed, critical thinking is considered to be an essential component of managerial work (Clokie \& Fourie, 2016) and a key element of graduate learning outcomes in many business programs (e.g. Cyphert, forthcoming; Lovelace, Eggers \& Dyck, 2016). Yet, as Bloch and Spataro (2014) found, the majority of employers do not find levels of critical thinking in graduates sufficient. 


\section{LANGUAGE AND DISCOURSE AWARENESS IN MANAGEMENT EDUCATION 5}

This essay hopes to demonstrate that management education that aims to equip future graduates with critical thinking and communication skills could benefit from a more nuanced appreciation of language and communication. Drawing on examples taken from language- and discourse-centered scholarly work, I argue that the ability to notice, identify and account for linguistic and discourse phenomena ultimately leads to greater critical consciousness of communicative practices and more broadly of one's physical and social surroundings. Such ability, as one of my previous students noted, can be compared to the awakening experienced by the main protagonist in the 1999 blockbuster, The Matrix. After taking the red pill, Neo was made aware of the true nature of their reality, constituted by a computer program. Critical awareness of language allows students to experience their realities in a similar manner, understanding the role of language in managerial and business processes (Forman, 1999) in becoming a professional and a member of a professional community (Bremner, 2018), as well as how broader discourses shape and are shaped by language (Mautner, 2016). Such awakening can then lead to a general critical and questioning attitude towards assumptions that were previously taken for granted, specifically the role language plays in social control and in sustaining and reproducing unequal power relations (Fairclough, 1992). To return to our previous example, for instance, the "symbolic brand meanings" created by the call center's communication (Brannan et al., 2015, p. 48) enabled the company to manage the aspirations and expectations of employees and make them happily accept their otherwise mundane reality. Viewing this process through a critical analytical lens in class, for example, can enable students to consider/question the ethics of such manipulative techniques in the context of business success or employee retention and satisfaction.

The crucial importance of communication as an instrumental tool of "operating" and "competing" (see Czerniawska, 1997, above) is clearly reflected in industry needs. It is hard to find a job advertisement that does not list communication skills as a key requirement: a survey of nearly 15 million job postings shows that soft skills, specifically oral and written communication skills, are the most required skills across all occupations (Cushing \& Gantz, 2013). The Graduate Management Admission Council survey (2017) found that of the 959 surveyed companies, communication skills rank the highest among 


\section{LANGUAGE AND DISCOURSE AWARENESS IN MANAGEMENT EDUCATION 6}

the skills employers seek in recent graduates. In the UK, soft skills - including communication skills are valued over $£ 88$ billion in Gross Value Added to the UK economy each year (Development Economics, 2015).

However, as well as the instrumental role of language and communication as a means to complete work, communication is also the process through which people construct their social realities. Communication is the site in which both individual and organizational identities, meanings and intentions are jointly negotiated. For example, the way a high-profile leader talks about his or her successful life story to employees or an audience of aspiring graduates is often framed in a way that emphasizes the leader standing out from the crowd, and that s/he persevered despite all obstacles (Spector, 2016). Consequently, the way in which such leaders talk about their life stories, the language they use (or "discourse" as language-in-use) inevitably leads to the promotion and legitimization of power and status differences. The way the speakers draw on language-as-social practice, or the (so called "capital D") Discourse of difference and heroic leadership both legitimizes and further reinforces a certain way of how reality is viewed or understood. Crucially, thinking influenced by such framing can lead to the justification of power inequalities in a workplace, the romanticizing of leadership, and, as Clifton puts it, claim "the natural superiority of a leader who has the right stuff which others are lacking" (2017, p. 16).

Higher level critical thinking and enhanced communication skills are clearly necessary and, consequently, strategically important in business education (Robles, 2012). Yet, as Clokie and Fourie (2016) found, although the learning outcomes set in higher education courses do reflect employer needs, the learning does not seem to translate from the classroom to a workplace context. The authors identify the problem as a focus of teaching on low-level thinking and mechanical communication skills. As becomes apparent here, teaching of critical language awareness and discourse consciousness could provide a solution to this problem. However, I believe that there are obstacles preventing greater inclusion and a more nuanced appreciation of these subjects in business and management curricula. One such obstacle is perhaps that soft skills in general are still viewed as having lesser importance and prestige than 


\section{LANGUAGE AND DISCOURSE AWARENESS IN MANAGEMENT EDUCATION 7}

"hard”, technical skills (Beenen, Pichler, \& Davoudpour, 2018), and, as Mautner notes, "skills courses are often the curriculum's poor relations (...) regarded as far removed from the pinnacle of intellectual endeavor" (2016, p. 10). Another reason may also be that the complexities of delivering such subjects are underestimated. Publications about language-related issues drawing on faux-scientific approaches to language continue to be published (see e.g. McVeigh, 2018 on the use of linguistic determinism in economic research), and communication training programs are often conducted by professionals without sufficient theoretical knowledge of communication (e.g. drama teachers, actors or ex-business professionals). To change these perceptions and draw greater attention to the crucial role of communication, this essay proposes three steps: first, to establish interdisciplinary conversation to bring together organizational scholarship and linguistics in research and teaching; second, to shift attention from communication training as skill development to the development of analytical skills; and third, to use linguistic and discourse awareness as a basis for self-reflexive, responsible management practice. In what follows, I will first review in greater detail and in the context of management education the two, intertwining functions of language and communication, and then demonstrate how these relate to higher level thinking and analytical skills, which are crucial parts of the managerial skillset required for the modern workplace.

\section{Communication as a means of doing work}

Communication, when viewed from an instrumentalist perspective (Bremner, 2014), is a means of achieving one's personal goals, a means of doing work, a means of conveying information. In this sense, communication and linguistic skills are part of a technical skillset, a conceptualization which implies a direct correlation between the communicator's intentions, the appropriately applied linguistic, verbal and non-verbal strategies and the resulting outcomes. This approach has been found to "fit well with the instrumentalism that characterizes mainstream management and practice” (Weninger \& Kan, 2013, p. 60), and is therefore rarely challenged or questioned (see Koller, 2018). The instrumentalist 


\section{LANGUAGE AND DISCOURSE AWARENESS IN MANAGEMENT EDUCATION 8}

view affects communication teaching and training (see Hünerber \& Geile 2012), resulting on the one hand in the production of teaching materials that are based on hypothesized business needs removed from the context of actual workplace practices and, consequently, on the other hand, in linguistic regulation, the delivery of concrete formulae and lists of strategies that (allegedly) would lead to the achievement of specific, well-defined communicative goals. I will discuss these two interrelated issues in detail below.

In terms of the first point, the disconnect between teaching materials and the workplace has often been explored in previous scholarship: examples include the work of Brink and Costigan (2015), who surveyed business communication courses to find that presentation skills receive disproportionate attention when, in fact, these skills are considered to be of lesser importance in the workplace. This discrepancy is particularly problematic in second language education, where business communication is taught as part of Language for Specific Purposes (LSP) or English for Specific Purposes (ESP) courses (see Angouri, 2018). In her seminal work, Williams looked at the language actually used in meetings and language taught for meetings in ESP books (1988). She barely found any correspondence between the textbooks and what happened in real contexts, noting that the language used in real meetings was far more complex than the teaching materials led students to believe.

Given the disconnect between teaching materials and real workplace contexts, more and more scholars advocate that teaching and training should respond to the needs of the workplace and reflect what happens in real life. Educators propose that one way to achieve this is the use of authentic, naturally occurring texts and interactional data in the classroom as a basis for reflection and discussion (Chan, 2017; Koester, 2010; Schnurr, 2013). The importance of drawing on empirical, real-life data in research and then in teaching is well articulated by Schnurr (2013), who argues that "although authentic data (for example in the form of audio and video recordings or written documents) are admittedly harder to obtain, (...) they are vital if we are to understand the complexities and implication of academic research in the (professional) real world." (p. 179). 


\section{LANGUAGE AND DISCOURSE AWARENESS IN MANAGEMENT EDUCATION 9}

As Bremner (2010) found, the discrepancies between the content of business communication textbooks and real life may lead to serious shortcomings resulting from the materials' disregard for such complexities, the wider and closer context of work, culture and power in the teaching of communication skills. His observations may explain the discrepancies between employer needs and teaching, both in terms of general managerial knowledge and specifically soft skills education in management (Baldwin, Pierce, Joines, \& Farouk, 2011). As Clokie and Fourie (2016) note, focusing on higher level thinking and analytical skills would provide a solution to bridging this gap. Based on previous literature some of these higher level skills include analytical skills that enable students to understand the perspectives of others (Baldwin et al. 2011), critical - or as Priem (2018) puts it "skeptical"- text reading skills (p. 379), critical thinking skills (Lovelace et al., 2016) or skills that "transcend typical disciplinary divisions - encompassing technological concerns, intergroup relations, non-verbal and chronemic awareness, relationship competence" (Waldeck et al., 2012, p. 237). As these cited works attest, there is a clear drive in management education to acknowledge and teach such thinking skills. As I hope to demonstrate below, the teaching of critical language awareness and discourse consciousness represents an excellent way to achieve this goal.

To initiate such change in teaching, however, examination of naturally occurring discourse should gain greater attention in research beyond the distinct corners of applied linguistics and discourse studies. Observations regarding language use, linguistic competency, strategies and norms often appear in business and organizational literature, but the claims tend to be based on theoretical considerations, interviews, experience reports and case studies rather than examination of actual discourse (cf. Skovholt \& Svennevig, 2006) or, as Mautner observes, focus on discourse is “couched in 'macro' terms," examining broad themes, without sufficient engagement with the "micro" level, where one investigates the linguistic devices that are used to express these themes (2017, p. 612).

Computer-mediated communication, and specifically leading and managing people in the virtual realm, is a good example demonstrating that the lack of a clear understanding of how exactly people 


\section{LANGUAGE AND DISCOURSE AWARENESS IN MANAGEMENT EDUCATION 10}

communicate may have serious consequences. For example, the teaching and training of digital business communication has taken a very dismissive and simplifying attitude to practices that help people inscribe nuances of spoken language into digital writing (such as using emoticons and ALL CAPS; for a critique see Loglia \& Bower, 2016). This is because the prevalent approaches to the analysis of virtual communication in management scholarship are participant interviews, surveys and laboratory experiments (see Purvanova, 2014), which grant only fleeting attention to what actually takes place in specific workplace contexts when, for example, colleagues use Instant Messenger.

Take, for instance, the following conversation that takes place via instant messaging (IM) between two colleagues who are in geographically distant locations (adapted from Darics, 2017). Fabiana is Andrew's boss, the regional lead of the team, and, in this conversation fragment, she is enquiring about who is going to take the minutes at their next meeting:

(Fabiana, Regional Lead/Asia; Andrew, Specialist/India).

1. Fabiana $|10: 58|$ do u know who is taking minute?

2. Andrew | 10:59 | No, normally I think Cailey herself takes the notes.

3. Fabiana $|10: 59|$ i dun think so... oh oh

4. Fabiana $|10: 59|$ Mary said she is not the one taking either

5. Andrew | 11:00 | Uhhh... in the past, whenever Cailey didn't assign responsibility explicitly to someone, she herself was doing the needful.

6. Fabiana | 11:01 | oh... ok

7. Andrew | 11:01 | I hope that applies today too

8. Fabiana | 11:01 | me too.. ha ha.. :-P

What we see here is Fabiana and Andrew discussing the person who is going to take minutes (Lines 2-4). Andrew's suggestion in Line 2 is rejected by Fabiana (Line 3). Andrew is in a difficult position: he has to disagree with Fabiana (his boss) and repeat the original information (as in Line 2). The communicative strategies in his response reveal how he addresses the tension that arises from having 


\section{LANGUAGE AND DISCOURSE AWARENESS IN MANAGEMENT EDUCATION 11}

to contradict someone in a higher hierarchical position (Line 5): he uses "Uhhh," a turn-initial pragmatic marker and an ellipsis mark. "Uhh" and/or a short gap in spoken interaction is typically used to introduce and soften the imposition created by contradicting information: despite the generally economizing efforts not to type more than necessary in IM, Andrew's use of these strategies is clear evidence of his attention to power and hierarchy differences in communication. Fabiana's response in Line 6 shows that the effort Andrew invested in mitigating the possible tension created by the contradiction has paid off: Fabiana's "oh" in Line 6 is at the turn-initial position and, along with the ellipsis mark "..." and "ok," signal the change in her knowledge and orientation. However, what is important for us to note here is that, contentwise, Fabiana's message (Line 6) would mean exactly the same without the use of "oh" and the ellipsis. Her use of these otherwise meaningless and perhaps even "unprofessional" cues played an important role in the way she indicated her understanding, signaling her thinking process and perhaps disclosing her emotional involvement in the interaction. In addition, she goes on to "laugh" in Line 8, both with what we call textual laughter as well as a "tongue-sticking-out" emoticon, leading to what Nardi et al. (2000) call, "friendly responsiveness" and generally collegial ambience. This example demonstrates that when everyday communication practices of virtual team members and leaders are examined, using strategies that are traditionally dismissed as "unprofessional" (Guffey \& Loewy, 2010, p. 114) plays a crucial role in negotiating organizational hierarchy, communicating collegiality and affect, and also in emphasizing, clarifying or disambiguating meaning and intentions.

We can learn an important lesson from drawing attention to the shortcomings of the scholarship that is concerned with language- and communication-related issues in management and organization studies without engaging naturally occurring interactional data: namely that there is not enough acknowledgement of disciplines making language use the object of their inquiry. Mautner (2016) speculates that the lack of acknowledgement of the importance of linguistics/discourse analytic expertise might be because language is often regarded as something of a "free-for-all" (p. 234). To enable a much clearer understanding of how communication happens in the workplace, and consequently to be able to translate 


\section{LANGUAGE AND DISCOURSE AWARENESS IN MANAGEMENT EDUCATION 12}

this knowledge to nurture effective, skillful communicators and critical thinkers, our first task is then to create opportunities for real interdisciplinary efforts in research. While a continuous effort is apparent to bring together approaches concerned with the minutiae of language and organizational research (Darics \& Clifton, 2018; Hargie, Stapleton, \& Tourish, 2010; Mautner, 2016; 2017; Putnam \& Fairhurst, 2001), as Grant and Iedema point out, such studies are still few and far between (2005, p. 39).

I have previously noted two interrelated issues with potential to affect the teaching of communication in business schools. First, as discussed above, insufficient engagement with empirical, real-life interactional data affects curricula. Closely related is the second issue, namely the traditionally prescriptive nature of communication education in business and management. Prescriptivism, pre-set formulae and do and don't lists offer what Mautner calls, “easy recipes and quick fixes," which are, however, "ill-suited to deal with the ever changing complexity that contemporary organizations throw at a manager" (2016, p. 4). Training effective communication skills using such an approach will not produce better "skilled" or "empowered" communicators, however. As Cameron, a prominent linguist, attests, "it cannot produce those things, because it negates the single most important ability of a truly skilled communicator: the ability to assess what is going on in a situation and choose strategies that are likely to be effective in that situation" (2000, p. 154). To give a specific example, Baldwin et al. (2011) mention the divide between a manager being able to list the rules of effective performance evaluation, and his/her ability to transfer models of effective performance management to effective handling of a situation, for instance when deciding how to approach an upset employee, or help them to get beyond defensiveness and commit to a personal improvement plan (p. 587). While management education literature contains ample advice on how to establish trust and create rapport in similar situations, managers, as Clifton (2012) notes are left to their "own intuitive devices to employ discursive strategies that 'do' (...) establishing a rapport" and, even if advice is given, "it is usually presented in the form of simplified scripts based on intuition and recollection rather than direct observation of what actually happens" 


\section{LANGUAGE AND DISCOURSE AWARENESS IN MANAGEMENT EDUCATION 13}

(p. 285). It is unsurprising therefore that there are increasingly loud calls for a shift from the prescriptive business communication teaching tradition to an approach that is based on observation, reflection and awareness raising (Darics \& Koller, 2018; Marra, 2013), the basis of which should be real-life data and research that addresses these, as I have proposed in the section above (see also Chan, 2017). To achieve paradigmatic change in the perception and education of communication skills, our second task is to steer away from communication training as skill development and instead focus on raising language and discourse awareness and training students to analyze communication and texts, using their analyses as a basis of reflection and discussion. This approach is particularly important if we consider the role language plays in organizational processes, as we will discuss next.

\section{Understanding communication as a process of social construction}

The role language plays in constructing our social realities is now a well-established school of thought (e.g. Jian, Schmisseur, \& Fairhurst, 2008). In a prominent line of organizational and management scholarship, as Cooren et al. (2011) explain, communication is not simply viewed as a "vehicle for the expression of pre-existing 'realities'; rather, it is the means by which organizations are established, composed, designed, and sustained. Organizations are (...) ongoing and precarious accomplishments realized, experienced, and identified primarily - if not exclusively - in communication processes" (p. 1150). Acknowledgement of the role of language in the constitution and reproduction of social realities - the "linguistic turn" - has led to increased attention to language and communication in organizational scholarship (Phillips \& Oswick, 2012). However, despite the burgeoning body of linguistically turned organizational and management research, as pointed out by Musson, Cohen and Tietze as early as 1999 and again in 2003, 2005 and 2007, the centrality of language in organizational processes (with a few exceptions) is not always addressed in management curricula. The authors argue that management education that denies students discursive consciousness perpetuates the theory/practice divide so typical of the field (Cohen, Musson, \& Tietze, 2005; Musson, Cohen, \& Tietze, 2007). 


\section{LANGUAGE AND DISCOURSE AWARENESS IN MANAGEMENT EDUCATION 14}

Why, then, should language and discourse awareness be considered key managerial skills and why have they not been advocated more widely in management education and in the business sphere in general? Addressing the first part of the question, the sheer volume of work that examines organizational or business phenomena through the language lens provides evidence of the multitude of arenas where managers have to be conscious and aware of the role of language: for example the recent Routledge Handbook of Language in the Workplace (Vine, 2017), the text by Darics and Koller on Language in Business, Language at Work (2017), the Handbook of Business Communication (Mautner and Reiner, 2017), and, specifically, Mautner's chapter (2017) are a testimony of the scale and breadth of areas of business and management intertwined with and dependent on language. To give a specific example of change management, managing change can be - and in organizational scholarship is increasingly viewed as the management of meaning because the success of change initiatives depends greatly on how those affected make sense of and buy into them (Ford \& Ford, 1995). A manager's ability to assess the uptake of and reaction to a change initiative is therefore a crucial skill. However, as Darics and Clifton (2018) note, despite the prevalent advice for managers to help them develop listening skills (e.g. Lawrence, 2015) or cultural sensitivity (e.g. Driskill \& Benton, 2011), little help is offered for aspiring change initiators as to what to listen for and how exactly to interpret meanings to shed light on patterns of collective thinking during a change process. The authors argue that by raising awareness of the linguistic resources used to construct a story, change initiators will not only be able to understand the stories employees tell about organizational change but will also be able to devise strategies to deal with employee sense-making. Importantly, Darics and Clifton also argue that such linguistic awareness leads to discursive consciousness, which is hoped to "prompt reflection on the morality of applying widely circulating Discourses to particular situations" (2018, p. 11) - for instance, the application of ageing and neoliberal discourses in the justification of change processes in a local hospice. This point takes us to the issue raised in the second part of our initial question, namely why the centrality of language in management processes does not receive greater attention. 


\section{LANGUAGE AND DISCOURSE AWARENESS IN MANAGEMENT EDUCATION 15}

Naturally, there may be many answers to this: as we noted earlier, this may occur because of the lower prestige of such awareness when compared to "hard" management theories, or perhaps resistance from both students and their teachers to venturing out of their disciplinary comfort zones. I believe that the answer may also lie in the "byproduct" of the linguistic turn in organizational management scholarship: criticality.

The pursuit of profitability, efficiency, productivity, employee buy-in and even employee well-being requires management to take a stance on political and moral values (Grey, 2004). Management is therefore never neutral. Heightened attention to discourse as a social practice and the role language plays in how we constitute, negotiate or perceive our reality inevitably leads to the exposure of the inherently political nature of management and examination of the relationship between discourse, control and power (Mumby, 2013). However, despite the proliferation of critical approaches in organizational scholarship (see Phillips \& Oswick, 2012) and increasingly in business discourse research (Koller, 2018), research has found that critical thinking could potentially be incorporated to a much greater extent, and in developmental stages in management training (Bloch \& Spataro, 2014; Cyphert, forthcoming). Currently, the typical business school curriculum, as Mautner (2017, p. 622) observes, incorporates:

"a heavy dose of functional expert knowledge, most of which rests on the seemingly immutable conceptual foundations of the market economy. By contrast, ideas, models and discourses that challenge these foundations are generally marginalized, if present at all. The pattern is repeated in and constantly reinforced by popular textbooks, often sold in their tens or hundreds of thousands, and by the dissemination of canonical knowledge in lecture halls across the globe."

Training in critical thinking, as is increasingly required by employers (Bloch \& Spataro, 2014) and the ever changing nature of the modern workplace (see the increasing attention to critical thinking in strategic management - e.g. Priem, 2018) cannot evolve without such criticality also turning inwards. 


\section{LANGUAGE AND DISCOURSE AWARENESS IN MANAGEMENT EDUCATION 16}

Management, as Critical Management Studies scholars have long argued, "needs always to be taught in ways that explicitly acknowledge the political, ethical, and philosophical nature of its practice" (Grey, 2004, p. 180), and examination of how such political, ethical and philosophical values are created, negotiated and perpetuated in and through discourse is an inevitable first step. This approach, however, brings to the surface uncomfortable realizations about the deep conflicts inherent in the relationship between organizations and individuals (Mumby, 2013) about the basis of decision-making of those in power (Deetz \& Brown, 2004) and issues related to agency (or the lack of this) (Weninger \& Kan, 2013).

Challenging the taken-for-granted and asking questions about how power and control are extorted in communication processes is an uncomfortable task. In my teaching I often experience the tension that arises from the need to conform to the norms and requirements of a workplace and the awareness of the power relationships, economic rewards and presumptions that sustain those norms. One example I have previously mentioned is the classwork based on the study of employee branding techniques used by a call center (Brannan, Parsons \& Priola, 2011). In this task students are asked to evaluate the ethics of manipulative strategies in light of business theories that indicate that employees identifying with organizational goals and values is crucial to the success of an organization (Brannan, Parsons \& Priola, 2011).

My intention - in class, and here - is not to promote criticality that would, in the long run, prevent organizations from thriving. Rather, my aim is to draw attention to the importance of critical consciousness of one's environment, including critical awareness of the role language - and communication more broadly - plays in creating and perpetuating these environments, including unequal power relations and social injustice.

Take active listening skills, for example. In a recent paper, Spataro and Bloch (2018) make a compelling case for the inclusion of active listening skill training in management curricula. They advocate 


\section{LANGUAGE AND DISCOURSE AWARENESS IN MANAGEMENT EDUCATION 17}

observation of and reflection on video material as a way of raising awareness of the importance of active listening in management practice. Arguably, however, such awareness-raising efforts should not stop at the level of noticing the instrumental function of active listening: students can also benefit from becoming aware of its political function. In appraisal interviews, for example, lack of active listening is not necessarily simply a skills-related problem, but rather an enactment of supervisory authority. Scheuer (2014) found that lack of active listening cues (such as backchannel signals, repetition of what has been said, probing questions and non-verbal cues such as nodding) might come across as a professional effort to give employees the space to talk. However, such behavior takes from employees the chance to actually engage in a discussion about the problems they experience. By showing only minimum or no affiliation while an employee talks, supervisors exclude themselves from active interaction; instead, they offer assurance and advice after the employee stops talking. Not engaging in active listening is therefore a convenient "way out" for the manager, enabling them to avoid taking part in discussion about problems that might challenge or critique organizational practices.

This example also shows just how important it is for the managers of the future to develop an awareness of the complexity of communication and the ways it can be used to enact power or reinforce injustice. Such awareness, it is hoped, will lead to the nurturing of better informed, more critical and more thoughtful managers (Musson, Cohen \& Tietze, 2007). The importance of this agenda cannot be overstated. It is hard to find an area of organizational life where such a critical lens would not be warranted: from exposing the cultural and linguistic disadvantage of candidates in promotion and job interviews (and challenging managers' own cultural predispositions) (Roberts, 2011; Roberts \& Campbell, 2005; Scheuer 2014), to critically examining the function and appropriateness of linguistic practices such as teasing, jocular abuse, swearing and rudeness in management discourse (Ladegaard, 2012; Mak \& Darics, 2017; Schnurr, 2009), and from understanding how cultural, linguistic and gender differences manifest in communication and influence participation in and management of workplace activities (Alvesson \& Billig, 1997; Angouri, 2010, 2018; Baxter, 2011) to exposing the role of language in 


\section{LANGUAGE AND DISCOURSE AWARENESS IN MANAGEMENT EDUCATION 18}

justifying questionable business decisions (Spicer, 2018; Amernic \& Craig, 2006) or shifting blame and avoiding responsibility (Darics \& Koller, 2019; Hargie et al., 2010). The final step is therefore to embrace the critical stance: management education needs to encourage students to use their knowledge to challenge the taken-for-granted, as a way to nurture higher order cognitive skills but also to develop self-reflexive, responsible management practice in the hope of challenging unfair work practices (see Roberts, 2011). As Koller notes, this practice "may not change the socio-economic system in which it is embedded, but it can effect changes in discursive practice to make (management) less exclusionary and more balanced, and lead to more respect and participation” (2018, p. 37).

\section{Language awareness, discourse awareness and beyond}

In this essay I have argued that management education would benefit from a more nuanced appreciation of communication. I demonstrated its complex and all-encompassing nature, as a means of doing work and as a site of social construction. In the preceding sections I proposed three steps with potential to lead to changes in perceptions and to greater focus on communication education in management training:

1) Increasing interdisciplinary efforts to bring together organizational scholarship and linguistics in research and teaching;

2) Steering away from communication training as skill development, focusing on raising language awareness and the development of analytical skills;

3) Using linguistic and discourse awareness as a basis for self-reflexive, responsible management practice.

The first step - reconciliation of business and linguistics - is not easy, especially because neither of the fields share a common ground in theory and established methodology, not to mention priorities, criteria and terminology (see Grant \& Iedema, 2005; Hünerberg \& Geile, 2012). However, the insights provided by the combination of these fields have been proven to be very successful (see, for example 


\section{LANGUAGE AND DISCOURSE AWARENESS IN MANAGEMENT EDUCATION 19}

Linguistic Profiling for Professionals consultancy https://www.nottingham.ac.uk/lipp/) and provide extensive resources for teaching and training materials that reflect what actually happens in the real world of work (see Darics \& Koller, 2018). Colleagues in the business school are therefore encouraged to form alliances with those in language-centered disciplines (see also Mautner, 2016), both for collaborative research and collaborative program design, even (or perhaps specifically) in areas where such alliance is not evident or straightforward. Take, for example, entrepreneurship where good communication skills are essential to success and are key for addressing wide and varied audiences across a range of communication channels, as well as a pre-requisite for more specific "entrepreneurial skills" such as getting people behind an idea and convincing others of the value of an opportunity (Chell, 2013). However, scholarship that addresses language and communication in entrepreneurship is thus far limited (Parhankangas \& Darics, forthcoming). Engaging in or drawing on scholarship that provides empirical evidence based on real-life interactional or textual data would help to address this problem. Interdisciplinary collaboration in research and teaching, as Forman attests, will lead business schools to "experience benefits in both their managerial communication curricula and in their larger mission to educate professionals in both the art and science of management" (1999, p. 16).

Such alliances are therefore crucial to realization of the second step: the nurturing of (critical) discourse analysts instead of "mere" communicators. In business communication this approach will allow course designers and educators to address what Marra calls "practical concerns" - for example, how to meet the needs of learners from assorted backgrounds, on diverse career trajectories, and with different workplace goals (2013, p. 180). Bremner's prescription for the training of discourse analysts is a "heavy diet of exposure, awareness raising and discussion" which will, he believes, equip students with the knowledge to achieve their communication goals and also contribute to their discourse awareness regarding organizational and social realities (2018, p. 174).

Arguably, awareness of language and discourse does not necessitate training in discourse analysis people can notice linguistic practices without explicit knowledge of discourse analysis and linguistics. 


\section{LANGUAGE AND DISCOURSE AWARENESS IN MANAGEMENT EDUCATION 20}

While this may be true, three things need to be mentioned. Exposure to discourse analytical work, both through learning about the results of previous scholarship and actually conducting analyses, has proven benefits. First, discourse analytical knowledge empowers people to notice and make explicit previously unnoticed phenomena: Llewellyn and Harrison (2006), for example, surveyed employees about their impressions of PR and corporate documents and found that their interviewees spoke "more explicitly and confidently about aspects of language where they had a grasp of relevant terminology" (p. 580). Second, discourse analytical knowledge can make visible, and thus actionable, issues in management that are complex and hard to account for, such as problems related to the multicultural workplace (Angouri, 2018) or female leadership (Baxter, 2017). To achieve this, I again call for increased interdisciplinary efforts between business and management educators and those who have made language and discourse their profession and object of research.

The two disciplinary camps, however, as Mautner (2016) notes, may be closer to each other than originally thought - physically and metaphorically. The growing number of relevant publications that emerge from linguistics departments, especially work that draws on empirical data and promotes the previously argued for analytical skills and critical thinking, is excellent evidence of the latter, and perhaps a good starting point for future collaborations (e.g. Bremner, 2018; Darics \& Koller, 2018, Schnurr, 2013).

My attempt in this essay to gain a deeper understanding of language and discourse in management has an admittedly practical aim: my hope is that such understanding leads to a change in perception of the importance of such awareness, and that my argument influences decision-making in program design. Such a change in attitude and acknowledgement is implicit - as Cushing and Gantz (2013) note what have previously been known as "soft skills" have now become "in demand" skills. These skills are necessary for the future success not only of those aspiring to fill high-level management positions, but "all students across the academic continuum and in the broader, civic economy" (Cushing \& Gantz, 2013). As well as empowering future managers, critical language awareness will lead to more aware, 


\section{LANGUAGE AND DISCOURSE AWARENESS IN MANAGEMENT EDUCATION 21}

conscious citizens, in terms of text consumption, and, it is hoped, more responsible, ethical text production in positions of power. In the era of fake news, unprecedented public manipulation (Martin, 2014; also Priem, 2018), and management fads hidden under hard-to-decode management jargon (Spicer, 2018), and the era ruled by visionary, religious-like leadership gurus (Clifton, 2017; Greatbatch \& Clark, 2005), such awareness should be a priority.

\section{References}

Alvesson, M. \& Billig, Y. (1997). Understanding Gender and Organizations. London: Sage Amernic, J. H., \& Craig, R. (2006). CEO-speak: The language of corporate leadership. London: McGill-Queen's University Press.

Andrews, J., \& Higson, H. (2008). Graduate employability, "soft skills" versus "hard” business knowledge: A European study. Higher Education in Europe, 33, pp. 411-422.

Angouri, J. (2010). 'If we know about culture it will be easier to work with one another': developing skills for handling corporate meetings with multinational participation. Language and Intercultural Communication, 10(3), 206-224.

Angouri, J. (2018). Culture, Discourse, and the Workplace. London: Routledge.

Artess, J., Hooley, T. \& Mellors-Bourne, R. (2017) Employability: A review of the literature 2012 to 2016. A report for the Higher Education Academy. Retrieved from https://www.heacademy.ac.uk/knowledge-hub/employability-review-literature-2012-2016

Baldwin, T., Pierce, J., Joines, R., \& Farouk, S. (2011). The elusiveness of applied management knowledge: A critical challenge for management educators. Academy of Management Learning \& Education, 10(4): 583-605.

Baxter, J. (2011). Survival or success? A critical exploration of the use of 'double-voiced discourse' by women business leaders in the UK. Discourse \& Communication, 5(3), 231-245. 


\section{LANGUAGE AND DISCOURSE AWARENESS IN MANAGEMENT EDUCATION 22}

Baxter, J. (2017). Resolving a gender and language problem in women's leadership: Consultancy research in workplace discourse. Discourse \& Communication, 11(2), 141. doi $10.1177 / 1750481317691858$

Beenen, G., Pichler, S., \& Davoudpour, S. (2018). Interpersonal Skills in MBA Admissions: How Are They Conceptualized and Assessed?. Journal Of Management Education, 42(1), 34-54.

Bloch, J. and Spataro, S.E. (2014). Cultivating Critical-Thinking Dispositions Throughout the Business Curriculum. Business and Professional Communication Quarterly. 77(3). 249-265.

Brannan, M.J., Parsons, E. and Priola, V., (2011). Branded lives: the production and consumption of meaning at work. Cheltenham: Edward Elgar.

Brannan, M. J., Parsons, E., \& Priola, V. (2015). Brands at work: the search for meaning in mundane work. Organization Studies, 36(1), 29-53.

Branson, R. (2014). How language shapes the way we work. Retrieved from https://www.virgin.com/richardbranson/ how-language-shapes-the-way-we-work.

Bremner, S. (2010). Collaborative writing: Bridging the gap between the textbook and the workplace. English for Specific Purposes, 29(2), 121-132.

Bremner, S. (2014). Critical wastelands: Business communications textbooks and the capitalist enterprise. Paper presented at the 5th CADAAD Conference (Critical Approaches to Discourse Analysis Across Disciplines), Budapest, Hungary.

Bremner, S. (2018). Workplace writing. Beyond the text. London, New York: Routledge.

Brink, K. E. \& Costigan, R.D. (2015). Oral Communication Skills: Are the Priorities of the Workplace and AACSB-Accredited Business Programs Aligned?. Academy of Management Learning \& Education, 14 (2), 205-221.

Cameron, D. (2000). Good to talk?: living and working in a communication culture. London; Thousand Oaks, California: Sage. 


\section{LANGUAGE AND DISCOURSE AWARENESS IN MANAGEMENT EDUCATION 23}

Chan, C. S. (2017). Investigating a research-informed teaching idea: The use of transcripts of authentic workplace talk in the teaching of spoken business English. English For Specific Purposes, 46, pp. 72-89. doi:10.1016/j.esp.2016.12.002

Chell, E. (2013). Review of skill and the entrepreneurial process. International Journal of Entrepreneurial Behaviour and Research, 19(1), 6-31.

Clifton, J. (2012). “Doing” trust in workplace interaction. In S. Măda, \& R. Săftoiu (Eds.), Professional communication across languages and cultures (pp. 107-134). Philadelphia, PA: John Benjamins.

Clifton, J. (2017) The in situ construction of leader identity in a leader's life story during an alumni talk to MBA students. Leadership. https://doi.org/10.1177/1742715017706644

Clokie, T. L., \& Fourie, E. (2016). Graduate employability and communication competence: are undergraduates taught relevant skills? Business and Professional Communication Quarterly. 79 (4), 442463.

Cohen, L., Musson, G., \& Tietze, S. (2005). Teaching communication to business and management students: a view from the United Kingdom. Management Communication Quarterly, 19(2), 279-286. doi:10.1177/0893318905278536

Cooren, T., Kuhn, T., Cornelissen, J.P. \& Clark, T. (2011). Communication, organizing and organization: an overview and introduction to the special issue. Organization Studies. 32(9), 1149-1170.

Crawford, M. B. (2009). Shop class as soulcraft: An inquiry into the value of work. New York: Penguin Press.

Creelman, V. (2015). Sheer outrage: Negotiating customer dissatisfaction and interaction in the blogosphere. In Darics, E. (Ed.) Digital business discourse (pp. 160-185) London: Palgrave Macmillan

Cushing, A., \& Gantz, J. F. (2013). Skills requirements for tomorrow's best jobs. Helping educators provide students with skills and tools they need. (White paper No. 243853). Framingham, USA: IDC. 


\section{LANGUAGE AND DISCOURSE AWARENESS IN MANAGEMENT EDUCATION 24}

Czerniawska, F. (1997). Corporate speak. The use of language in business. Basingstoke, London: Macmillan Business.

Cyphert, D. (forthcoming). A Developmental Framework for Professional Communication Competence: Language Awareness in Context. In Darics, E., (ed) Language Awareness in Professional Practice. Changing Perceptions About Soft Skills. Cambridge: Cambridge University Press

Darics, E. (2017). E-leadership, or "How to be boss in Instant Messaging?" The role of non-verbal communication. International Journal of Business Communication. https://doi.org/10.1177/2329488416685068

Darics, E., \& Clifton, J. (2018). Making Applied Linguistics Applicable to Business Practice. Discourse Analysis as a Management Tool. Applied Linguistics. https://doi.org/10.1093/applin/amy040

Darics, E. and Koller, V. (2018). Language in Business, Language at work. Basingstoke: Palgrave Macmillan.

Darics, E., \& Koller, V. (2019). Social Actors “to Go": An Analytical Toolkit to Explore Agency in Business Discourse and Communication. Business and Professional Communication Quarterly. https://doi.org/10.1177/2329490619828367

Deetz, S. \& Brown, D. (2004) Conceptualising involvement, participation and workplace decision processes: a communication theory perspective. In D. Tourish \& O. Hargie. (Eds.). Key Issues in Organizational Communication (pp. 172-187). London: Routledge.

Development Economics Ltd. (2015). The Value of Soft Skills to the UK Economy. Retrieved from http://backingsoftskills.co.uk/The\%20Value\%20of\%20Soft\%20Skills\%20to\%20the\%20UK\%20Economy.pdf Driskill, G.\& A. Brenton. (2011). Organisational Culture in Action: A Cultural Analysis Workbook. 2nd ed. Thousand Oaks, California: Sage. 


\section{LANGUAGE AND DISCOURSE AWARENESS IN MANAGEMENT EDUCATION 25}

Fägersten, K. B. (2015). Snuff said! Conflicting employee and corporate interests in the pursuit of a tobacco client. In Darics, E. (Ed.) Digital business discourse (pp. 142-159). Palgrave Macmillan, London.

Fairclough, N. (1992). Critical language awareness. Harlow: Longman.

Financial Services Skills Council, The City of London. (2006, September). Graduate skills and recruitment in the city. Retrieved from http://www.cityoflondon.gov.uk/business/ economic-research-andinformation/research-publications/Documents/2007-2000/ Graduate\%20Skills\%20and\%20Recruitment\%20in\%20the\%20City.pdf

Ford, J. \&Ford, L. (1995). The role of conversations in producing intentional change in organizations. Academy of Management Review, 20(3), 541-570.

Forman, J. (1999). Management communication and MBA education: An argument for management literacy. Selections, 15(3), 9-15.

Girginova, K. (2015). Social CEOs: Tweeting as a constitutive form of organizational communication. In Darics, E. Digital business discourse (pp. 40-60). Palgrave Macmillan, London.

Government Office for Science (2017). Future of Skills and Lifelong Learning. (Foresight report). Retrieved from: https://www.gov.uk/government/publications/future-of-skills-and-lifelong-learning

Graduate Management Admission Council. (2017). Corporate Recruiters Survey Report. Retrieved from https://www.gmac.com/market-intelligence-and-research/research-library/employment-outlook/2017-corporate-recruiters-survey-report.aspx

Grant, D., \& Iedema, R. (2005). Discourse analysis and the study of organizations. Text. Interdisciplinary Journal for the Study of Discourse, 25(1), 37-66.

Greatbatch, D. \& Clark, T. (2005) Management speak: why we listen to what management gurus tell us. Abingdon, Oxon: Routledge.

Grey, C. (2004) 'Reinventing Business Schools: The Contribution of Critical Management Education'. Academy of Management Learning and Education, 3(2). 178-87. 


\section{LANGUAGE AND DISCOURSE AWARENESS IN MANAGEMENT EDUCATION 26}

Guffey, M. E., \& Loewy, D. (2010). Essentials of business communication (8th ed.). Mason, OH: Cengage Learning.

Hargie, O., Stapleton, K., \& Tourish, D. (2010). Interpretations of CEO public apologies for the banking crisis: attributions of blame and avoidance of responsibility. Organization, 17(6), 721-742.

Hünerberg, R. and Geile, A. (2012). Language awareness as a challenge for business. Language awareness, 21(1-2), 215-234.

Jian, G., Schmisseur, A.M. And Fairhurst, G. T. (2008) Organizational discourse and communication: the progeny of Proteus. Discourse \& Communication. 2(3). 299-320.

Koester, A. (2010). Workplace discourse. London: Continuum.

Koller, V. (2018) Critical Discourse Studies. In B. Vine (Ed.), The Routledge Handbook of Language in the Workplace (pp. 27-39). London, New York: Routledge.

Ladegaard, H. J. (2012). Rudeness as a discursive strategy in leadership discourse: Culture, power and gender in a Hong Kong workplace. Journal of Pragmatics, 44(12), 1661-1679

Lawrence, P. (2015). Leading change: how successful leaders approach change management. London: Kogan Page.

Llewellyn, N., \& Harrison, A. (2006). Resisting corporate communications: Insights into folk linguistics. Human Relations, 59(4). 567-596.

Loglia, J. M., \& Bower, C. A. (2016). Emoticons in business communication. Is the :) worth it? In S. Y. Tettegah \& S. U. Noble (Eds.), Emotions, technology, and design (pp. 37-54). London, England: Elsevier.

Lovelace, K. J., Eggers, F., \& Dyck, L. R. (2016). I do and I understand: Assessing the utility of webbased management simulations to develop critical thinking skills. Academy of Management Learning \& Education, 15(1), 100-121.

Mak, B. C. and Darics, E. (2017). Swearing at colleagues through instant messaging: Changing norms of social interaction in the workplace context. In. K. B. Fägersten \& K. Stapleton, Advances in 


\section{LANGUAGE AND DISCOURSE AWARENESS IN MANAGEMENT EDUCATION 27}

Swearing Research. New Languages, New Contexts. (pp. 43-64). Amsterdam: John Benjamins Publishing.

Mara, M. (2013). English in the Workplace. In B. Paltridge and S. Starfield (Eds.) The Handbook of English For Specific Purposes. (pp. 175-192). Chichester, UK:Wiley-Blackwell

Martin, D. (2014). McLuhan's nightmare. Journal of Business Strategy, 35(6), 58-65.

Mautner, G. (2016). Discourse and management. Hampshire, England: Palgrave Macmillan.

Mautner, G. (2017) Organizational Discourse. In G. Mautner, G. and F Reiner,(Eds). Handbook of Business Communication, Linguistic Approaches (pp. 609-628). Boston/Berlin: Mouton De Gruyter.

Mautner, G. \& Reiner, F. (Eds). (2017). Handbook of Business Communication, Linguistic Approaches. Boston/Berlin: Mouton De Gruyter.

Mumby, D. K. (2013) Organizational Communication. A Critical Approach. London: Sage.

Musson, G. \& Cohen, L. (1999) Understanding Language Processes. A Neglected Skill in the Management Curriculum. Management Learning. 30(1), 27-42.

Musson, G., Cohen, L., \& Tietze, S. (2007). Pedagogy and the 'Linguistic Turn'. Developing Understanding Through Semiotics. Management Learning, 38(1), 45-60. doi:10.1177/1350507607073022

Nardi, B. A., Whittaker, S., \& Bradner, E. (2000, December). Interaction and outeraction: instant messaging in action. In Proceedings of the 2000 ACM conference on Computer supported cooperative work. pp. 79-88.

Parhankangas, A. \& Darics, E. (forthcoming). Language and Communication in Entrepreneurship Research. In Darics, E., (ed) Language Awareness in Professional Practice. Changing Perceptions About Soft Skills. Cambridge: Cambridge University Press

Phillips, N. \& Oswick, C. (2012). Organizational Discourse: Domains, Debates, and Directions. The Academy of Management Annals, 6(1), 435-481. doi: 10.1080/19416520.2012.681558

Priem, R. (2018). Toward Becoming a Complete Teacher of Strategic Management. Academy of Management Learning \& Education, 17 (3), 374-388. DOI: 10.5465/amle.2017.0237 


\section{LANGUAGE AND DISCOURSE AWARENESS IN MANAGEMENT EDUCATION 28}

Purvanova R. K. (2014). Face-to-Face Versus Virtual Teams: What Have We Really Learned?. The Psychologist-Manager Journal, 17(1), 2-29. doi:10.1037/mgr0000009

Putnam, L. \& Fairhurst, G. (2001). Discourse analysis in organizations: issues and concerns. In Jablin, F. M. \& Putnam, L. (Eds.) The New Handbook of Organizational Communication: Advances in Theory, Research and Methods. (pp. 235-268). Newbury Park: SAGE

Ritter, B. A., Small, E. E., Mortimer, J. W., \& Doll, J. L. (2018). Designing Management Curriculum for Workplace Readiness: Developing Students’ Soft Skills. Journal Of Management Education, 42(1), 80-103. doi:10.1177/1052562917703679

Roberts, C. (2011). Gatekeeping discourse in employment interview. In Sarangi, S., Christopher, C. (Eds.) Handbook of Communication in Organisations and Professions. (pp. 407-432) Berlin: Mouton De Gruyter.

Roberts, C. \& Campbell, S. (2005). Fitting stories into boxes: Rhetorical and textual constraints on candidates’ performances in British job interviews. Journal of Applied Linguistics 2(1), 45-73.

Robles, M. M. (2012). Executive perceptions of the top 10 soft skills needed in today's workplace. Business and Professional Communication Quarterly, 75, pp. 453-465.

Rust, C. \& Froud, L. (2011). „Personal literacy": the vital, yet often overlooked, graduate attribute. Journal of Teaching and Learning for Graduate Employability, 2(1), 28-40.

Scheuer, J., (2014). Managing employees' talk about problems in work in performance appraisal interviews. Discourse Studies, 16(3), 407-429.

Schnurr, S. (2009). Constructing leader identities through teasing at work. Journal Of Pragmatics, 4(1), 1125-1138. doi:10.1016/j.pragma.2008.10.002

Schnurr, S. (2013). Exploring Professional Communication. Language in Action. London and New York: Routledge. 


\section{LANGUAGE AND DISCOURSE AWARENESS IN MANAGEMENT EDUCATION 29}

Skovholt, K., \& Svennevig, J. (2006). Email copies in workplace interaction. Journal of Computer-

Mediated Communication, 12(1), 42-65.

Spataro, S. E., \& Bloch, J. (2018). “Can You Repeat That?” Teaching Active Listening in Management Education. Journal Of Management Education, 42(2), 168-198. doi:10.1177/1052562917748696

Spector, B. A. (2016). Discourse on Leadership. Cambridge: Cambridge University Press.

Spicer, A. (2018). Business bullshit. London: Routledge

Tietze, S., Cohen, L., \& Musson, G. (2003). Understanding organizations through language. London; Thousand Oaks, California: Sage.

Thomson, N. (2003). Communication and Language. A Handbook of Theory and Practice. Basingstoke: Palgrave Macmillan.

UK Commission Employer Survey. (2015). Employer Skill Survey 2015. Retrieved from: https://www.gov.uk/government/uploads/system/uploads/attachment_data/file/525449/UKC004_Summary_Report_May_.pdf

Vine, B. (Ed.) (2018), The Routledge Handbook of Language in the Workplace. London, New York: Routledge.

Waldeck, J., Durante, C., Helmuth, B., \& Marcia, B. (2012). Communication in a Changing World: Contemporary Perspectives on Business Communication Competence. Journal Of Education For Business, 87(4), 230-240. doi:10.1080/08832323.2011.608388

Weninger, C., \& Kan, K. H. (2013). (Critical) Language awareness in business communication. English For Specific Purposes, 32, pp. 59-71. doi:10.1016/j.esp.2012.09.002

Williams, C. (2010). The discursive construction of the 'competent' learner-worker: from key competencies to 'employability skills. Studies in Continuing Education, 27(1), 33-49.

Williams, M. (1988). Language Taught for Meetings and Language Used in Meetings: Is there Anything in Common?. Applied Linguistics, 9(1), 45-58. 